Tersedia online di: http://ejournal-balitbang.kkp.go.id/index.php/JP
e-mail:jurnalpari@gmail.com
JURNAL PARI
volume 6 Nomor 1 Juli 2020
p-ISSN: 2502-0730
e-ISSN : 2549-0133

\title{
MANAJEMEN KEARSIPAN DALAM MENUNJANG KEGIATAN ADMINISTRASI PELAYANAN PUBLIK PADA SEKOLAH USAHA PERIKANAN MENENGAH SORONG DI LINGKUNGAN KEMENTERIAN KELAUTAN DAN PERIKANAN
}

\author{
Arfa Fakaubun \\ Sekolah Usaha Perikanan Menengah Sorong \\ Diterima tanggal : 4 Mei 2020 Diterima setelah perbaikan : 9 Juli 2020 \\ Disetutujui terbit : 23 Juli 2020
}

\begin{abstract}
ABSTRAK
Dilihat dari perkembangan ilmu pengetahuan dan teknologi yang sangat pesat dewasa ini membawa pengaruh terhadap seluruh kegiatan yang dilakukan oleh setiap instansi, oleh sebab itu perlu ditingkatkan manajemen kearsipan dalam menunjang kegiatan administarsi pengelolaan arsip yang baik dan benar agar menjadi sumber informasi publik. karena sangat menunjang kecepatan dan ketepatan penyajian informasi, serta dapat membantu semua pihak dalam rangka melancarkan penyelesaian tugas, guna mencapai tujuan yang telah ditentukan. maka perlu dipahami tentang seluk beluk kearsipan sehingga dapat mengatasi masalah yang dihadapi oleh instansi Pemerintah maupun swasta, seperti pada Sekolah Usaha Perikanan Menengah Sorong yang notabenya sebagai Sekolah Kejuruan di bidang Perikanan, maka perlu di dukung dengan Sarana dan Prasarana Pendidikan yang disebut dengan manajemen kearsipan, sehingga dapat mewujudkan informasi pelayanan administrasi yang baik dan benar, yang diamanatkan dalam Undang-Undang Nomor 43 Tahun 2009 tentang Kearsipan dan Undang-Undang Nomor 20 Tahun 2003 tentang Sistem Pendidikan Nasional.
\end{abstract}

\section{Kata Kunci : Arsip sebagai sarana dan prasarana pendidikan}

\begin{abstract}
Judging from the rapid development of science and technology today under the influence of all activities carried out by each agency, therefore it is necessary to improve the management of archives in supporting the administration of good and correct records management in order to become a source of public information. because it greatly supports the speed and accuracy of the presentation of information, and can help all parties in order to expedite the completion of the task, in order to achieve the specified goals. then it needs to be understood about the ins and outs of archiving so as to overcome the problems faced by government and private agencies, such as the Sorong Middle Fisheries Business School which in fact is a Vocational School in the field of Fisheries, it needs to be supported with Educational Facilities and Infrastructure called archival management, so that it can realize good and correct administrative service information, which is mandated in Act Number 43 of 2009 concerning Archives and Act Number 20 of 2003 concerning the National Education System.
\end{abstract}

Keywords : Archives as educational facilities and infrastructure 


\section{PENDAHULUAN}

Seperti yang kita ketahui bahwa arsip menjadi bagian yang sangat penting bagi suatu instansi pemerintah maupun organiasi dalam pemeliharaan sumber informasi. Perkembangan dan kegiatan suatu instansi pemerintah maupun suatu organisasi akan terjaga jika arsip yang menjadi sumber informasi di instansi maupun organisasi tersebut dijaga dengan baik. Pegawai administrasi yang merupakan salah satu komponen di suatu instansi pemerintah maupun organisasi yang berwenang dalam pengelolaan arsip, sehingga mereka diharuskan memiliki kompetensi tertentu agar manajemen kegiatan pemeliharaan arsip sebagai informasi publik baik secara manual maupun secara elektronik dapat berjalan dengan baik dan terpercaya.

Undang-Undang Aparatur Sipil Negara Nomor 5 Tahun 2014 bahwa untuk mewujudkan aparatur sipil negara sebagai bagian dari reformasi birokrasi, perlu ditetapkan aparatur sipil negara sebagai profesi yang memiliki kewajiban mengelola dan mengembangkan dirinya dan wajib mempertanggung jawabkan kinerja dan menerapkan prinsip merit dalam pelaksanaan manajemen aparatur sipil negara.

Berdasarkan bunyi undang-undang diatas, maka pada Unit Pelaksana Teknis Sekolah Usaha Perikanan Menengah Sorong sebagai lembaga Pendidikan sudah seharusnya dan sepantasnya dapat mewujudkan citacita dan tujuan negara serta mempertahankan Negara Kesatuan Republik Indonesia, dengan mengelola dan menjaga kestabilan kearsipan sebagai aset negara atau sebagai sejarah bagi bangsa dan Negara Republik Indonesia, serta menjadi sumber informasi sarana dan prasarana bagi dunia pendidikan. Dan kenyataannya telah terjadi sumber informasi karena didunia pendidikan banyak yang membutuhkan informasi kearsipan baik manual maupun elektronik sebagai bahan penelitian maupun pembuatan makalah, misalnya dari peserta didik maupun mahasiswa yang selalu magang atau penelitian di Sekolah Usaha Perikanan Menengah Sorong untuk mendaptkan informasi atau bukti kegiatan maupun pembelajaran yang dihasilkan dari instansi ini sebagai pedoman dan persyaratan dalam pembuatan makalah maupun studi. Dari hal seperti itulah, maka tujuan dari terbentuknya manajemen kearsipan dalam menunjang kegiatan administrasi pelayanan publik sangatlah penting sehingga perlu di implementasikan di Sekolah Usaha Perikanan Menengah Sorong..

Sedangkan Undang-Undang Nomor 43 Tahun 2009 tentang Kearsipan sudah sangat benar penjelasannya, maka Pengertian Kearsipan adalah hal-hal yang berkaitan dengan arsip. Arsip adalah rekaman kegiatan atau peristiwa dalam berbagai bentuk dan media sesuai dengan perkembangan teknologi informasi dan komunikasi yang dibuat dan diterima oleh lembaga negara, pemerintahan daerah, lembaga pendidikan, perusahaan, organisasi politik, organisasi kemasyarakatan, dan perseorangan dalam pelaksanaan kehidupan bermasyarakat, berbangsa dan bernegara.

Tujuan pengelolaan kerasipan adalah menyelenggarakan pengurusan arsip yang bermutu melalui program seleksi yang secara efektif dan efisien sehingga tercipta kondisi kerasipan dalam suatu lembaga penidikan seperti pada Sekolah Usaha Perikanan Menengah Sorong, pegawai setiap saat melayani peserta didik dari pagi sampai dengan pagi pula, sehingga perlu adanya manajemen kearsipan yang baik agar terciptanya administrasi peserta didik yang akurat dan relefan.

Karena Sekolah Usaha Perikanan Menengah Sorong dibawah naungan Kementerian Kelautan dan Perikanan yang kehidupan peserta didik sehari-hari berupa belajar dan ekstrakulikuler di asrama, sehingga dokumen-dokumen peserta didik harus dijaga dengan baik, agar sewaktu-waktu ada peserta didik maupun orang tua peserta didik yang membutuhkan dokumen peserta didik sebagai persyaratan dalam pengurusan kebutuhan orang tuanya, maka harus dapat dilayani dengan cepat dan baik. Karena di Sekolah Usaha Perikanan Menengah Sorong yang menciptakan dan mengelola arsip peserta didik baik secara manual maupun secara elektronik adalah bagian administrasi Kesiswaan, maka yang disebut dengan kearsipan sebagai informasi pelayanan publik baik dari dalam instansi maupun dari luar instansi harus secara efektif dan efisiens.

Efektifitas manajemen kearsipan sangat dibutuhkan dalam pelaksanaan administrasi pada Sekolah Usaha Perikanan Menengah Sorong, karena arsip merupakan pusat ingatan bagi setiap kegiatan dalam suatu lembaga Pendidikan, tanpa arsip tidak mungkin tenaga pendidik maupun tenaga kependidikan dapat mengingat semua catatan dan dokumen-dokumen secara lengkap. Karena itu suatu lembaga Pendidikan dalam mengelola kearsipan harus memperhatikan sistem manajemen arsip yang sesuai dengan keadaan organisasi dalam mencapai tujuannya, jika sistem manajemen kearsipan dapat berjalan dengan baik dan efektif, maka kegiatan administrasi dapat pula berjalan dengan baik dan efektif pula. 
Di dalam Peraturan Menteri Kelautan dan Perikanan tentang Kearsipan di Lingkungan Kementerian Kelautan dan Perikanan Nomor 67 Tahun 2016 bahwa untuk menjamin ketersediaan arsip yang autentik dan terpercaya, serta mendinamiskan sistem kearsipan, diperlukan penyelenggaraan kearsipan yang sesuai dengan prinsip, kaidah, dan standar kearsipan. Arsip adalah rekaman kegiatan atau peristiwa dalam berbagai bentuk dan media sesuai dengan perkembangan teknologi informasi dan komunikasi yang dibuat dan diterima oleh Kementerian dalam pelaksanaan kehidupan bermasyarakat, berbangsa, dan bernegara.

\section{TINJAUAN PUSTAKA}

Ada beberapa pendapat yang di kemukakan oleh beberapa para ahli untuk memperoleh gambaran yang jelas mengenai pengertian kearsipan dan arsip adalah sebagai berikut :

Pengertian Kearsipan menurut Donni dan Agus (2013) yang berpendapat bahwa kearsipan adalah suatu aktifitas yang berhubungan dengan kegiatan pengelolaan arsip atau yang disebut dengan administrasi arsip.

Sedangkan Maulana (1979) mengemukakan bahwa arsip adalah tulisan yang dapat memberikan keterangan tentang kejadian-kejadian dan pelaksanaan organisasi, yang dapat berwujud suratmenyurat, data dan bahan-bahan yang dapat berbicara dan dapat memberi keterangan yang jelas dan tepat. Data atau bahan itu bisa berupa barang cetakan, kartukartu lembaran dan buku catatan yang berisi korespondensi, dapat juga berbentuk hasil penelitian, skripsi dan lain-lain.

Menurut Reitzfeld (dalam Laksmi dkk, 2008) ada tujuh nilai dari suatu arsip, terutama untuk keperluan menentukan jangka waktu penyimpanan, yaitu : Manfaat administrasi, Manfaat hukum, Manfaat keuangan, Manfaat untuk pembuatan kebijakan, Manfaat untuk pelaksanaan kegiatan, Manfaat untuk kegunaan sejarah, Manfaat untuk penelitian.

Manajemen arsip menurut Laksmi dkk (2008) adalah pelaksanaan pengawasan sistematik dan ilmiah terhadap semua informasi terekam yang dibutuhkan oleh sebuah organisasi untuk menjalankan usahanya. la mengawasi sistem penyimpanan arsip organisasi dan memberikan pelayanan-pelayanan yang diperlukan. Dengan kata lain, manajemen kearsipan melakukan pengawasan sistematik mulai dari penciptaan atau penerimaan arsip, kemudian pemrosesan, penyebaran, pengorganisasian, penyimpanan, sampai pada akhir pemusnahan arsip.

Laksmi dkk (2008) menyatakan bahwa manajemen kearsipan berfungsi mengawasi sistem penyimpanan arsip dan memberikan pelayanan-pelayanan yang diperlukan. Dalam rangka mencapai fungsi tersebut, maka manajemen kearsipan dilakukan melalui inventaris arsip, retensi arsip serta penilaian dan penyusutan arsip.

Menurut Wursanto (1991) bahwa pengertian kearsipan adalah proses kegiatan pengurusan atau pengaturan arsip dengan mempergunakan suatu sistem tertentu, sehingga arsip-arsip dapat di temukan kembali dengan mudah dan cepat apabila sewaktuwaktu di perlukan.

Sedangkan yang dikatakan oleh Sugiarto (2005) bahwa kearsipan merupakan dasar dari pemeliharaan surat mulai dari penciptaan, penyimpanan sampai penyusutan sehinga apabila diperlukan dapat ditemukan kembali.

Menurur Barto (2005) bahwa pengerian arsiparis adalah pusat ingatan, sumber informasi dan sebagai alat pengawasan yang sangat di perlukan dalam setiap organisasi dalam rangka kegiatan perencanaan. Adapun pengertian kearsipan menurut Sedarmayanti (2008) bahwa kearsipan adalah kegiatan mengatur dan menyusun arsip dalam suatu tatanan yang sistematis dan logis, berupa menyimpan, serta merawat arsip untuk digunakan secara aman dan ekonomis.

Dari defenisi diatas, dapat disimpulkan bahwa kearsipan merupakan proses dari awal bentuknya surat/warkat serta penyimpanan hingga penyusutan arsip yang ciptakan dan disimpan untuk kemungkinan dipergunakan pada waktu yang akan datang.

Menurut Gie (1996) di dalam bukunya Administrasi Perkantoran Moderen yang berbunyi bahwa arsip adalah kumpulan dokumen yang disimpan secara sistematis agar setiap diperlukan dapat ditemukan kembali secara cepat dan tepat. dalam UndangUndang bahwa naskah-naskah yang berisikan halhal yang terhubung satu dengan yang lainnya di himpun dalam suatu berkas tersendiri mengenai masalah yang sama.

Sedangkan menurut Suraja (2006) bahwa pengertian arsip adalah naskah atau catatan yang dibuat dan di terima oleh suatu organisasi pemerintah, swasta dan perorangan mengenai suatu peristiwa atau hak dalam kehidupannya, dalam bentuk apapun baik dalam keadaan tunggal maupun berkelompok yang 
memiliki nilai guna tertentu, dan di simpan secara sistematis sehingga bilamana di perlukan dapat di temukan dengan mudah dan cepat.

Menurut fungsi dan kegunaannya arsip dapat di golongkan menjadi arsip dinamis dan arsip statis yang menurut undang-undang nomor 7 tahun 1971 yang di maksud dengan arsip dinamis dan arsip statis adalah sebagai berikut :

1. Arsip dinamis yang di gunakan secara langsung dalam perencanaan, pelaksanaan, penyelenggaraan kehidupan kebangsaan pada umumnya atau di pergunakan secara langsung dalam penyelenggaraan administrasi negara. Yang dapat di katakan bahwa arsip dinamis adalah arsiparsip yang di pergunakan secara langsung dalam kegiatan perkantoran sehari-hari. Arsip dinamis dapat di rincikan sebagai berikut:

- Arip aktif adalah arsip yang masih di pergunakan secara terus menerus bagi kelangsungan pekerjaan di lingkungan unit pengolah bagi suatu organisasi perkantoran

- Arsip inaktif adalah arsip yang tidak lagi dipergunakan secara terus menerus atau frekuensi penggunaannya sudah menurun atau hanya di pergunakan sebagai referensi.

2. Arsip statis adalah arsip yang tidak di pergunakan secara langsung, namun dapat di pergunakan untuk perencanaan, penyelenggaraan kehidupan kebangsaan pada umumnya maupun untuk penyelenggaraan kehidupan sehari-hari sebagai administrasi negara, dan ini merupakan pertanggung jawaban nasional bagi kegiatan pemerintah dan nilai gunanya penting untuk generasi yang akan datang.

Menurut Choiriyah (2007) arsip adalah warkat yang merupakan setiap catatan tertulis baik dalam bentuk gambar ataupun bagang yang memuat keteranganketerangan mengenai suatu objek /pokok persoalan maupun suatu peristiwa yang dibuat orang untuk membantu daya ingat orang. Dari defenisi tersebut dapat disimpulkan bahwa arsip merupakan suatu kumpulan dokumen yang disusun dan disimpan secara teratur di dalam lemari box arsip agar sertiap kali dibutuhkan dapat ditemukan kembali dengan cepat dan mudah.

Pengertian Sistem manajemen kearsipan menurut Laksmi (2008) bahwa Sistem manajemen kearsipan adalah Pelaksanaan pengawasan sistematik dan ilmiah terhadap semua informasi yang terekam yang dibutuhkan oleh sebuah organisasi untuk mendukung tugas-tugas atau kegiatan-kegiatan di dalam organisasi agar tercapai efektifitas maupun efisien.
Sedangkan menurut Sugiarto (2005) bahwa Sistem Manajemen Kearsipan merupakan salah satu bagian dari Manajemen Perkantoran yang hakekatnya pada pengurusan dokumen sedemikian rupa agar dokumendokumen yang dikelola dan para petugas kearsipan harus benar-benar akan membantu serta mendukung aktivitas manajemen secara keseluruhan.

Dari pengertian diatas dapat disimpulkan bahwa Manajemen kearsipan merupakan suatu gabungan antara seni dan ilmu yang mengatur tentang kearsipan mulai dari penyimpanan hingga penyusutan yang disusun secara teratur agar dapat ditemukan kembali dengan cepat dan baik. Ketiga arsip harus dapat di temukan kembali secara fisik maupun informasinya, arsip dapat di bedahkan dengan non arsip, karena non arsip merupakan keseluruhan informasi dalam bentuk yang tidak nyata seperti percakapan biasa, namun non arsip akan bisa menjadi arsip. Hal ini yang di kemukakan oleh Milburn D. Smith ill.

Pengertian nilai guna arsip menurut sedarmayanti (2003) adalah suatu proses penilaian arsip untuk menentukan jangka waktu penyimpanan atau retensi arsip yang di dasarkan atas pengkajian terhadap isi arsip, yang penataannya berhubungan dengan arsiparsip lainnya.

\section{METODE}

Metode yang digunakan adalah jenis penelitian deskriptif kualitatif penelitian yang bertujuan untuk mendapatkan pemahaman yang mendalam tentang masalah-masalah manusia dan tugas fungsinya, metode Kualitatif merupakan metode penelitian naturalistik karena penelitiannya dilakukan pada kondisi yang alamiah karena data atau dokumen yang terkumpul dan analisisnya lebih bersifat kualitatif. Analisis data yang dilakukan bersifat induktif berdasarkan fakta-fakta yang ditemukan di lapangan dan kemudian dikonstruksikan menjadi hipotesis atau teori. Metode tersebut dimaksudkan untuk mempelajari dan meneliti bagaimana cara pengelolaan terhadap kearsipan sebagai sarana dan prasarana pendidik dalam menunjang manajemen administrasi pelayanan publik yang baik dan efektif.

Lokasi Penelitian berada di Sekolah Usaha Perikanan Menengah Sorong yang

beralamat di Jalan Jenderal Ahmat Yani No.32 Kelurahan Klakublik Kota Sorong Provinsi Papua Barat.

Jenis dan sumber data terdiri dari data primer dan data sekunder : 
- Data Primer adalah data yang di peroleh langsung dari lapangan disamping dokumen tertulis, biasanya didapatkan dari subjek penelitian dengan cara melakukan pengamatan, percobaan atau wawancara langsung dengan responden.

- Data Sekunder adalah data yang tidak langsung diperoleh dari sumber pertama, dan telah tersusun dalam bentuk dokumen tertulis. data-data yang digunakan adalah melalui buku-buku referensi serta Peraturan Perundang-Undangan yang ada relevansinya dengan objek yang akan di bahas, data sekunder ini yang akan diperoleh dengan berpedoman pada literatur-literatur sehingga dinamakan penelitian kepustakaan.

Penelitian Kepustakaan adalah penelitian yang dilakukan dengan mempelajari bahan-bahan hukum yang berkaitan dengan data sekunder yang terdiri dari:

1. Undang-Undang Dasar Tahun 1945

2. Undang-Undang Nomor 5 Tahun 2014 tentang Aparatur Sipil Negara (ASN)

3. Undang-Undang Nomor 43 Tahun 2009 tentang Kearsipan

4. Undang-Undang Nomor 20 Tahun 2003 tentang Sistem Pendidikan Nasional

5. Peraturan Menteri Kelautan dan Perikanan

6. Buku-buku Kearsipan

7. Modul-modul Kearsipan

8. Majalah-majalah Kearsipan

\section{HASIL DAN PEMBAHASAN}

Menurut undang-undang nomor 43 tahun 2009 tentang Kearsipan, penyelenggaraan kearsipan adalah keseluruhan kegiatan meliputi kebijakan, pembinaan kearsipan dan pengelolaan arsip dalam suatu sistem kearsipan yang didukung oleh sumber daya manusia, prasarana dan sarana, serta sumber daya lainnya. Jadi manajemen pengelolaan kearsipan merupakan salah satu kegiatan penyelenggaraan kearsipan, di samping kebijakan dan pembinaan kearsipan.

Manajemen kearsipan adalah perencanaan, pengawasan, pengarahan, pengorganisasian, pelatihan, pengembangan dan aktivitas manajerial lain yang ditujukan atas kegiatan penciptaan, pemeliharaan, penggunaan dan penyusutan arsip dengan maksud untuk mencapai dokumentasi yang baik dan sesuai dengan kebijakan dan transaksi kegiatan yang riil, dan manajemen organisasi yang efektif dan efisien Undang-undang tentang Kearsipan tersebut mengelompokkan pengelolaan arsip menjadi dua yaitu pengelolaan arsip dinamis dan pengelolaan arsip statis.
Pengelolaan arsip dinamis adalah proses pengendalian arsip dinamis secara efisien, efektif, dan sistematis meliputi penciptaan, penggunaan, pemeliharaan dan penyusutan arsip. Sedangkan pengelolaan arsip statis adalah proses pengendalian arsip statis secara efisien, efektif dan sistematis meliputi akuisisi, pengolahan, preservasi, dan akses, (pemanfaatan, pendayagunaan, dan pelayanan publik) dalam suatu sistem kearsipan.

Unit Pelaksana Teknis Sekolah Usaha Perikanan Menengah Sorong sebagai unit kearsipan III hanya dapat mengelola arsip Dinamis, karena fungsi dari arsip dinamis adalah penciptaan arsip aktif dan pengelolaan arsip inaktif, yang berpedoman kepada Tata Naskah Dinas, Klasifikasi Arsip, Jadwal Retensi Arsip (JRA) dan Sistem Klasifikasi dan Keamanan dan Akses Arsip (SKKAA) di Lingkungan Kementerian Kelautan dan Perikanan. Sedangkan arsip statis dapat di kelola oleh Pusat yaitu eselon I dan II atau Unit Kearsipan I maupun unit kearsipan II di Lingkungan Kementerian Kelautan dan Perikanan adalah Biro Umum dan Badan Riset dan Sumber Daya Manusia Kelautan dan Perikanan.

Menurut Undang-Undang Nomor 43 Tahun 2009 tentang Kearsipan yang membedakan dua macam pengelolaan arsip seperti tersebut di atas, dapat dikatakan bahwa pengelolaan arsip dinamis dilakukan dengan tujuan untuk menjamin ketersediaan arsip dalam penyelenggaraan kegiatan sebagai bahan akuntabilitas kinerja dan alat bukti yang sah berdasarkan suatu sistem yang memenuhi persyaratan yang andal, sistematis, utuh, menyeluruh, dan sesuai dengan norma, standar, prosedur dan kriteria yang ditetapkan dalam Pedoman Tata Naskah Dinas. Selain itu pejabat atau orang yang bertanggungjawab dalam pengelolaan arsip dinamis wajib menjaga keautentikan, keutuhan, keamanan, dan keselamatan arsip yang dikelolanya. Jadi pada dasarnya tujuan pengelolaan arsip dinamis yaitu untuk menjamin ketersediaan arsip yang keautentikan, keutuhan, keamanan, dan keselamatan. Sedangkan pengelolaan arsip statis dilaksanakan dengan tujuan untuk menjamin keselamatan arsip sebagai bahan pertanggung jawaban bagi kehidupan berorganisasi, bermasyarakat, berbangsa, dan bernegara.

Pengaturan pengelolaan arsip statis secara nasional di perlukan untuk menjamin pelestarian memori kolektif bangsa secermat mungkin dan penggunaannya untuk kepentingan publik, serta penyelenggaraan kehidupan berbangsa dan bernegara. Hal itu di perlukan dalam rangka koordinasi kelembagaan secara nasional dan standar layanan kearsipan baik di lingkungan instansi-instansi 
pemerintah pusat maupun instansi perangkat daerah baik di lingkungan pemerintah provinsi maupun pemerintah kabupaten/kota. Dan di harapkan penyelenggaraan pengelolaan arsip yang efektif dan efisien dan pelestarian serta pendayagunaan arsip yang efektif secara nasional.

Yang dimaksud dengan peran dan kedudukan hukum arsiparis adalah yang berhubungan dengan fungsi dan peran dalam kegiatan kearsipan sejak penciptaan sampai dengan penyusutan, dan sampai dengan pemanfaatan arsip, serta kegiatan lainnya yang dilindungi secara sah oleh peraturan perundangundangan yang berlaku. Yang dimaksud dengan standar kualitas dan spesifikasi sarana dan prasarana kearsipan adalah ketentuan standar tentang kualitas, bahan, bentuk, ukuran, jenis, dan lain-lain yang dijadikan acuan atau pedoman dalam pengadaan dan penggunaan sarana dan prasarana kearsipan.

Peran penting arsip mempunyai fungsi sebagai pusat ingatan, sumber informasi dan alat pengawasan yang sangat diperlukan dalam setiap organisasi publik dalam rangka kegiatan perencanaan, penganalisaan, pengembangan, perumusan kebijakan, pengambilan keputusan, pembuatan laporan, akuntabilitas suatu kegiatan. Setiap kegiatan yang dilaksanakan, baik di dalam organisasi pemerintahan maupun swasta selalu ada kaitannya dengan masalah arsip. Fungsi arsip aktif harus dapat memberi dampak positif bagi keterbukaan informasi pada pelayanan publik seiring dengan penciptaan aparatur yang bersih dan berwibawa. Arsip mempunyai kontribusi dalam proses penyajian informasi bagi pimpinan untuk membuat keputusan dan merumuskan kebijakan, oleh sebab itu untuk dapat menyajikan informasi yang lengkap, cepat dan benar huruslah ada sistem dan prosedur kerja yang baik di bidang kearsipan. Untuk itu pengembangan kualitas dan kuantitas Sumber Daya Manusia dalam suatu organisasi dalam mengelola arsip dan peningkatan sarana dan prasarana pendukung kearsipan diharapkan mampu merubah citra arsip itu sendiri.

Yang dimaksud dengan meningkatkan kualitas pelayanan publik adalah penyelenggaraan kearsipan yang komprehensif dan terpadu dengan dukungan sumber daya manusia yang profesional serta sarana dan prasarana yang memadai akan meningkatkan kualitas pelayanan publik dalam memanfaatkan arsip yang dibutuhkan melalui ketersediaan arsip yang faktual, utuh, sistematis, autentik, terpercaya, dan dapat digunakan oleh publik.

Pada sebagian besar organisasi dibidang kearsipan, baik yang berorientasi keuntungan maupun tidak, Sumber Daya Manusia dan Sumber Dana adalah faktor yang paling menentukan keberhasilan kinerja dan pencapaian organisasi dimana mereka berada. Institusi manajemen arsip sebagai sebuah departemen tidak luput dari perlunya keberadaan Sumber Daya Manusia dan Sumber Dana yang andal yang sangat mendukung keberhasilan manajemen dalam menjalankan visi dan fungsinya dalam memberikan layanan maksimal kepada induk organisasinya.

Untuk merealisasikan hal tersebut perlu adanya suatu perubahan besar mengenai karakteristik pengelolaan arsip. Perubahan ini tidak saja menuntut biaya yang tidak sedikit untuk memberikan pelatihan dan Manajemen Kearsipan Dalam Menunjang Pelayanan publik pada lembaga pendidikan yang berkualitas tinggi, tetapi juga perubahan mental dari pengelola arsip itu sendiri.

Dalam suatu pengelolaan arsip sebagai informasi pelayanan publik, maka birokrasi pemerintah tentunya melakukan berbagai aktivitas yang berkaitan dengan pengelolaan informasi, yang dalam dunia moderen saat ini dilakukan dengan mempergunakan hasil-hasil ilmu teknik seperti komputer, telepon, dan berbagai peralatan mekanis lainnya dalam rangka mempercepat pengolahan, penyimpanan hingga penyampaian bahan informasi bagi publik maupun bagi kepentingan pembuatan keputusan internal organisasi itu sendiri. Setelah informasi diproses, maka kesemuanya disimpan dalam berbagai dokumen maupun arsip yang bernilai bagi organisasi, yang juga harus dikelola secara baik untuk dapat dipergunakan secara cepat, tepat dan cermat. Manajemen kearsipan merupakan sebutan untuk aktivitas pengelolaan dokumen atau arsip tersebut.

Manajemen kearsipan berkenaan dengan sistem, teknik dan metode penyimpanan dokumen-dokumen dan arsip-arsip yang memuat berbagai informasi penting yang dibutuhkan organisasi. Arsip sangatlah penting dalam suatu organisasi seperti pada Sekolah Usaha Perikanan Menengah Sorong, karena arsip merupakan sumber informasi dan wahana dokumentasi serta alat bukti yang sah, maka arsip merupakan bahan atau data untuk pengambilan suatu keputusan secara tepat, dan arsip sebagai suatu sistem dimana satu sama lainnya saling berkaitan dalam suatu ikatan yang utuh, karena arsip dapat menunjang suatu program kegiatan organisasi, baik dari segi perencanaan, pelaksanan maupun pengendalian tugas organisasi yang berada di lembanga pendidikan. 
Sumber informasi terekam yang memiliki fungsi yang sangat penting untuk menunjang proses kegiatan administrasi negara dan manajemen birokrasi, disamping itu arsip dapat pula dimanfaatkan oleh lembaga dan instansi, untuk mengatur pengelolaan arsip baik secara institusional maupun secara nasional. dan metode pengelolaan arsip yang di nilai memenuhi kebutuhan peningkatan efisiensi operasional instansi dan sekaligus kebutuhan pelestarian arsip yang di anggap memiliki nilai guna untuk kepentingan yang lebih luas, dalam rangka penyelenggaraan kehidupan berbangsa dan bernegara. Dalam hal ini dibutuhkan pengaturan mengenai pengelolaan arsip pada lembaga-lembaga atau organisasi pencipta arsip agar dapat mengelola arsip secara efisien untuk kepentingan akuntabilitas dan untuk kepentingan kolektif bangsa dalam rangka pertanggung jawaban nasional. Pengaturan secara nasional di perlukan dalam rangka pelestarian arsip sebagai memori kolektif bangsa agar dalam pengelolaan arsip keterkaitan dalam alur yang jelas antara lembaga-lembaga negara dan badan-badan pemerintah, baik dalam pengelolaan arsip dinamis maupun arsip statis.

Prosedur merupakan serangkaian tindakan yang tersusun secara sistematis, yang didasarkan pada suatu ketentuan yang diatur berdasarkan hasil kebijakan organisasi. Demikian pula prosedur yang berlaku pada penyelenggaraan kearsipan maupun pencipta arsip Unit Pelaksana Teknis Sekolah Usaha Perikanan Menengah Sorong tentunya merupakan suatu keputusan yang diambil oleh pemegang otoritas untuk menertibkan segala jenis arsip yang tersimpan agar tertatah lebih baik. Prosedur penyelenggaraan kearsipan harus mencerminkan pada prinsip-prinsip manajemen administrasi pelayanan publik yang lebih efektif dan efisien.

Langkah awal untuk mengantisipasi arsip agar terhindar dari kerusakan maka diperlukan suatu tindakan yang bersifat pencegahan, yaitu dilakukan tindakan fumigasi dengan cara melakukan perawatan berupa pembersihan dari debu ke semua berkas yang akan disimpan. Langkah-langkah tersebut perlu dilakukan agar arsip terhindar dari kerusakan yang diakibatkan oleh musuh-musuh arsip. Terutama bagi arsip yang memiliki nilai historis dan bersifat dinamis, perlu diambil tindakan dan langkah-langkah yang bersifat preventif. Bersifat preventif dimaksud adalah suatu tindakan yang dilakukan untuk mencegah sebelum arsip tersebut mengalami kerusakan atau dimakan oleh rayap atau mahluk lainnya, Sedangkan yang dimaksud arsip dinamis adalah arsip yang dianggap masih berguna untuk menunjang administrasi sehari-hari pada lembaga negara dan lembaga pemerintahan maupun lembaga pendidikan. Oleh karena itu penyimpanannya harus diperhatikan dan aman dari ancaman.

Dari kesimpulannya bahwa tindakan fumigasi sebagai antisipasi keamanan arsip, pada Unit Pelaksanaan Teknis Sekolah Usaha Perikanan Menengah Sorong kurang mendapat perhatian bagi perawatan maupun tempat penyimpanan arsip. Oleh karena itu perlu mendapat perhatian serius dari pimpinan lembaga, karena dapat membahayakan keadaan arsip atau juga kesehatan para petugas pelaksana kearsipan. Dalam kondisi demikian maka untuk menjamin keamanan arsip dan menjaga kesehatan para penyelenggara arsip tersebut sudah selayaknya jika pihak lembaga memperhatikan permasalahan yang terjadi. Terutama melakukan langkah-langkah kooperatif dan antisipatif demi terjaminnya keamanan arsip dan kesehatandan petugas arsip. karena yang dinamakan penataan dokumen atau arsip negara sangatlah penting sebagai upaya untuk memudahkan didalam penemuan kembali. Oleh karena itu penyimpanannya harus ditata sedemikian rupa agar dalam pencariannya tidak mengalami kesulitan.

Pelayanan kearsipan yang aman dan lancar merupakan dambaan bagi setiap orang, namun dalam kenyataan hampir di semua sektor pelayanan publik masih kurang memuaskan, sehingga sering terjadi kesenjangan antara harapan dan kenyataan. Hal tersebut terjadi karena banyak faktor yang mempengaruhi dan salah satunya faktor sumber daya manusia maupun sumber dana operasioanl. Para analis mengatakan bahwa faktor manusia merupakan determinan penting dalam menunjang kelancaran pelayanan khususnya terhadap pelayanan arsip, dengan pentingnya faktor tersebut tidak hanya cukup melihat dari sisi kuantitasnya, tetapi juga memperhatikan dari aspek kualitasnya. Kedua aspek tersebut perlu mendapat prioritas utama jika ingin meningkatkan kualitas pelayanan publik yang baik.

Pelayanan informasi data kearsipan merupakan bagian dari pelayanan kearsipan. Mengingat terbatasnya petugas pelaksana maupun sarana dan prasarana kearsipan, maka untuk keperluan tersebut belum dapat dilakukan secara optimal. Informasi data yang dapat diberikan kepada berbagai pihak yang memerlukan, hanya dapat dilakukan dengan cara manual. Sedangkan dengan cara komputerisasi nampaknya baru diaplikasikan sehingga perlu waktu relative lama, Oleh karena itu pelayanan untuk pemberian informasi data kepada pihak-pihak yang membutuhkan belum sepenuhnya dilakukan secara online. 
Sesuai hasil pengumpulan data menunjukkan bahwa kualitas pelaksana kearsipan pada Sekolah Usaha Perikanan Menengah Sorong sudah terbantu dengan adanya aplikasi Layanan Perkantoran Persuratan, disposisi dan arsip (e-layar) di Lingkungan Kementerian Kelautan dan Perikanan, karena didalamnya sudah terdapat beberapa bagian yaitu untuk penerimaan surat, pengiriman surat dan bahkan sebagai penyimpanan arsip yang namanya pengelolaan arsi secara elektonik.

Untuk di ketahui bahwa pada suatu instansi pemerintah tidaklah mudah dalam penanganan arsip, dan pasti ada saja kendalah yang mengakibatkan fatal karena tercecer dan hilangnya suatu arsip atau dokumen penting bagi kelancaran kegiatan maupun audit, oleh sebab itu perlu di terapkan sebuah sistem pengelolaan arsip agar dapat menunjang administrasi pelayanan publik yang baik seperti pada Sekolah Usaha Perikanan Menengah Sorong. Hal ini yang di sebut dengan Manajemen Kearsipan.

Yang dimaksud dengan arsip adalah rekaman informasi atau kegiatan surat di arahkan atau dikendalikan untuk di proses lebih lanjut. Proses surat dapat di lakukan dengan menggunakan buku agenda surat masuk atau keluar, penanganan sistem surat masuk dan surat keluar berisi kolom-kolom untuk mencatat surat masuk dan surat keluar serta untuk mengendalikan. Dapat di ketahui surat atau arsip yang ditangani dan merupakan langkah-langkah mempermudah jalannya surat tanpa harus membuat suatu kesalahan dalam membuang waktu untuk pencarian arsip. Sedangkan yang dimaksud dengan agenda adalah pencatatan surat keluar dan surat masuk dapat dipisahkan dengan menggunakan buku agenda surat masuk dan buku agenda surat keluar.

Pengelolaan surat maupun arsip pada Unit Pelaksana Teknis Sekolah Usaha Perikanan Menengah Sorong, berpedoman pada Peraturan Menteri Kelautan dan Perikanan Republik Indonesia Nomor 52/PERMEN-KP/2014 tentan Pedoman Umum Tata Naskah Dinas di Lingkungan Kementerian Kelautan dan Perikanan. sedangkan Pemberkasan arsip dan penyusutan arsip berpedoman pada Pearturan Menteri Kelautan dan Perikanan Republik Indonesia Nomor 53/PERMEN-KP/2014 tentang Sistem Pemberkasan Arsip, dan Nomor 50/PERMENKP/2014 tentang Penyusutan Arsip di Lingkungan Kementerian Kelautan dan Perikanan.

Sistem kode klasifikasi mengacu kepada Peraturan Menteri Kelautan dan Perikanan Nomor 67 Tahun 2016 tentang Kearsipan dan Jadwal Retensi Arsip (JRA) pada Lingkungan Kementerian Kelautan dan
Perikanan, dan sebagai pedoman dalam pemindahan arsip dari aktif ke inaktif adalah sebagai berikut :

- Pengelompokan surat atau arsip berdasarkan pada kode klasifikasi surat.

- Pengelompokan atau pemilahan jenis surat atau arsip

- Penguruta secara numerik berdasarkan pada pencatatan di buku agenda surat masuk dan buku agenda surat keluar

- Pencatatan dan pemindaian/scan di komputer untuk mempermudah pencairan/penelusuran kembali arsip, pemindaian hanya dilakukan pada arsip-arsip yang penting atau vital atau arsip yang memiliki frekuensi penggunaan yang sangat tinggi.

- Penataan arsip di odner/bindex pada lemari arsip

- Pemindahan arsip dari pencipta arsip ke pengelola arsip

- Penyusutan arsip yang sudah tidak bernilai guna lagi dan retensinya sudah menurun

- Penataan arsip di odner/bindex sesuai kode klasifikasi dan urutan nomor pencatatan agenda surat masuk dan surat keluar.

Penanganan surat masuk dan surat keluar, setiap surat masuk yang diterima dan surat keluar yang di kirim oleh Sekolah Usaha Perikanan Menengah Sorong mempunyai nilai yang sangat penting, baik sebagai alat komunikasi antara unit-unit kerja, sebagai informasi pelayanan publik, sebagai pusat ingatan, seabagai bukti autentik dan sekaligus dapat menunjukkan dinamika organisasi. Pengurusan surat di Sekolah Usaha Perikanan Menengah Sorong dengan menggunakan buku agenda yang merupakan suatu proses pencatatan surat mausk dan surat keluar, serta menggunakan buku distribusi maupun buku ekspedisi interen atau eksteren.

Menurut fungsi dan kegunaannya arsip terdiri dari arsip dinamis dan arsip statis, arsip aktif, arsip inaktif, statis, terjaga dan arsip umum adalah sebagai berikut: 1. Arsip dinamis adalah arsip yang digunakan secara langsung dalam kegiatan pencipta arsip dan disimpan selama jangka waktu tertentu.

2. Arsif aktif adalah Arsip yang frekuensi penggunaannya tinggi dan atau terus menerus

3. Arsip inaktif adalah arsip yang frekuensi penggunaannya telah menurun atau berkuran.

4. Arsip vital adalah arsip yang keberadaannya merupakan persyaratan dasar bagi kelangsungan operasional pencipta arsip, tidak dapat di perbaharui, dan tidak dapat tergantikan apabila rusak atau hilang

5. Arsip statis adalah arsip yang di hasilkan oleh pencipta arsip karena memiliki nilai guna kesejarahan, dan telah habis retensinya, sehingga keterangan di permanenkan, yang telah di verifikasi 
baik secara langsung maupun tidak langsung oleh Arsip Nasional Republik Indonesia dan/atau lembaga kearsipan.

6. Arsip terjaga adalah arsip negara yang berkaitan dengan keberadaan dan kelangsungan hidup bangsa dan negara yang harus di jaga keutuhan, keamanan dan keselamatannya

7. Arsip umum adalah arsip yang tidak termasuk dalam kategori arsip terjaga.

Manajemen kearsipan pada setiap kegiatan arsip sebagai bantuan data dan informasi, demikian juga pada kegiatan pengambilan keputusan juga dari bantuan data dan informasi yang benar dan dapat dihasilkan secara efektif dan efisien. Manajemen adalah para pemimpin yang bertugas membuat keputusan yang berkaitan dengan perencanaan, pelaksanaan, dan pengawasan dari masing-masing fungsi yang ada di perkantoran, baik pada tingkat manajemen menengah maupun manajemen bawah.

Dua pengertian di atas masing-masing dapat di jelaskan untuk kegiatan kearsipan adalah sebagai berikut, suatu rangkaian metode yang telah menjadi pola tetap dalam melakukan suatu pekerjaan yang merupakan suatu kebulatan sebagai prosedur penyimpanan arsip. Pengelolaan kearsipan adalah rangkaian kegiatan mengelola seluruh unsur yang digunakan atau terlibat di dalam proses pengurusan arsip, dan usaha pengelola kearsipan di lakukan melalui pelaksanaan fungsi-fungsi perencanaan, pengorganisasian, penyusunan personalia, pengarahan dan pengendalian atau pengawasan terhadap arsip dan sumber daya yang ada untuk pengurusan kearsipan.

Pelaksanaan manajemen dalam suatu organisasi bertujuan untuk mewujudkan efektifitas dan efesien kerja dalam mencapai tujuan dan hasil dari pelaksanan serangkaian kegiatan. Dalam kegiatan tersebut terdapat suatu rangkaian ketentuan-ketentuan mengenai cara penyimpanan arsip antara lain meliputi : memilah-milah meneliti, memadukan, mengklasifikasi, mengindeks, mempersiapkan tunjuk silang serta menyusun dan memfile. Kearsipan sebagai kelompok ilmu pengetahuan tertentu yang mempelajari tentang hal ihwal arsip dari perorangan, badan swasta atau organisasi pemerintah yang sangat penting untuk keperluan penelitian atau sumber ingatan di kemudian hari. Setiap kegiatan tersebut, baik dalam organisasi, pemerintah atau swasta selalu ada kaitannya dengan masalah arsip. Oleh karena itu untuk menyajikan informasi yang benar, lengkap dan cepat, maka haruslah ada manajemen dan prosedur kerja yang baik di dalam mengelola kearsipan sehingga arsip dapat menjadi pedoman bagi kelancaran pekerjaan. Namun pada dasarnya pegawai di Sekolah Usaha Perikanan Menengah Sorong pada umumnya masih tidak berfikir bahwa arsip itu penting, sehingga banyak arsip yang ada di unit-unit mereka yang belum dapat di kelolah dengan baik dan benar sehingga kalau ada yang membutuhkan arsip baik itu arsip negara maupun arsip untuk pengurusan masalah pribadi seperti kenaikan pangkat dll masih sulit di temukan karena pada tercecer di mana-mana dan tidak tahu arsip atau berkas ada di mana khususnya arsip aktif yang setiap hari atau sewaktuwaktu masih dibutuhkan. ini adalah suatu kelemahan pegawai dalam menegelola arsip pada Sekolah Usaha Perikanan Menengah Sorong.

Dengan kata lain setiap organisasi pasti memerlukan suatu unit yang mengelola segala sesuatu yang berhubungan dengan kegiatan administrasi, kegiatan administrasi merupakan kegiatan yang cakupannya luas, dan biasanya segala kegiatan administrasi diolah suatu unit tersendiri yang disebut dengan bagian administrasi, tata usaha, sekretariat kantor, urusan umum dll.

Kegiatan administrasi di suatu kantor pada dasarnya juga mempunyai suatu hasil seperti unitunit lain. Yang dimaksud dengan hasil atau produk dari suatu kantor adalah surat, dokumen, formulir dan laporan, pengelolaan surat, dokumen, formulir dan laporan yang dihasilkan dan yang diterima dari suatu kantor pada akhirnya akan berhubungan dengan kearsipan, sehingga yang disebut dengan kegiatan administrasi pada dasarnya adalah menghasilkan, menerima, mengolah dan menyimpan berbagai surat, dokumen, formulir, laporan dll. Salah satu sumber data adalah arsip, karena arsip adalah bukti dan rekaman dari kegiatan terdepan sampai kepada kegiatan pengambilan keputusan.

Adapun hambatan yang yang membuat arsip tertumpuk dan tidak tertatah dengan baik pada tempatnya meskipun ada yang pengelolanya, yang di karenakan kurangnya sarana dan prasarana yang memadai dalam penyimpanan dan penataan arsip, yang terdapat pada Sekolah Usaha Perikanan Menengah Sorong, sehingga di unit-unit kerja masingmasing seperti di ruangan Tata Usaha, Kepegawaian, Keuangan, Kesiswaan, Pengajaran, Kehumasan dan Sarana Pendidikan pada dasarnya masi belum sempurnah dalam menangani arsip di unit-unit tesebut, itu adalah salah satu faktor dalam mengelola arsip di Sekolah Usaha Perikanan Menengah Sorong.

Yang kita ketahui arsip merupakan salah satu hal yang sangat penting dan fundamental sehingga pertanggung jawaban dalam pengelolaan birokrasi 
baik pemerintah maupun pendidikan. Walaupun banyak permasalahan yang terjadi hanya diakibatkan oleh salah urus sistem penyimpanan arsip pada setiap organisasi atau sistem birokrasi pemerintah. Dalam pelaksanaan kegiatan kantor yang semakin berkembang, maka semakin banyak dokumen dan data-data maupun arsip yang terkumpul dan disimpan karena masih mempunyai nilai guna, sehingga perlu penyimpanan secara sistematis sehingga apabila dibutuhkan dapat diketemukan dengan mudah dan cepat. karena arsip sangatlah penting dalam perjalanan kehidupan sebuah instansi perkantoran, oleh karena itu untuk menjaga kehidupan arsip mulai dari tahap penciptaan, penggunaan, pemeliharaan dan pemindahan serta pemusnahan, maka diperluhkan sistem yang baik dan agar dapat diproses lebih baik pula.

Arsip yang ada pada suatu lembaga pemerintah atau swasta dan lebih terkhusus pada Sekolah Usaha Perikanan Menengah Sorong merupakan bahan resmi dari suatu perencanaan, pelaksanaan, penyelenggaraan kehidupan instansi pendidikan, juga berfungsi menyediakan bahan bukti untuk pertanggung jawaban kegiatan organisasi yang bersangkutan. Dengan demikian arsip diperlukan untuk keperluan pengambilan keputusan atau kebijakan baru oleh pimpinan intsansi atau perusahaan yang memerlukan data kearsipan. Karena kearsipan memegang peranan bagi kelancaran jalannya organisasi yaitu sebagai sumber informasi pelayanan publik dan sebagai pusat ingatan bagi organisasi, oleh karena itu perlu dilakukan dengan prosedur yang baik dan benar di dalam pengelolaan arsip pada unit pelaksana teknis Sekolah Usaha Perikanan Menengah Sorong.

Di samping pengertian pengelolaan dan sistem manajemen arsip, maka perlu difahami tentang daur hidup kearsipan, dalam daur hidup kearsipan terdiri dari beberapa tahap-tahapan dalam proses kehidupan arsip. Dan untuk menjaga daur hidup arsip harus berawal dari tahapan penciptaan, penggunaan, pemeliharaan dan pemindahan serta pemusnahannya, dalam pekerjaan penyimpanan arsip tidak hanya menyimpan saja, akan tetapi menyangkut penempatan dan penemuan kembali. penyimpanan arsip dikatakan baik apabila pada waktu diperluhkan dapat ditemukan kembali dengan mudah, cepat dan tepat.

Kalau berbicara tentang arsip, maka haru didukung juga dengan tempat atau ruangan penyimpanan arsip atau dokumen negara dalam suatu kantor pemerintahan, kalau kita hanya berbicara tentang arsip tapi tidak disertai dengan tempat atau ruangan arsip, maka pastilah arsip itu akan tetap menumpuk pada tempat dimana kita bekerja bisa di samping meja, diatas meja maupun di bawah meja. Itu juga yang terjadi di Sekolah Usaha Perikanan Menengah Sorong, karena berhubungan dengan tidak adanya anggaran untuk operasional ruangan kearsipan, sehingga belum efektif juga terhadap pengelolaan dan penyimpanan arsip pada tempatnya.

Hal tersebut juga bisa dikatakan sebagai hambatan dalam pelaksanaan sistem dalam pengelolaan kearsipan yang tidak efektif dan efisien. Dan apabila sampai tidak ada pengawasan terhadap pelaksanaan kearsipan, khususnya pelaksanaan penyimpanan berkas atau dokumen yang disebut dengan arsip aktif dan arsip inaktif.

Karena pada hakekatnya kalau di suatu instansi pemerintah atau swasta pasti ada yang namanya arsip, dan arsip pun harus memiliki tempat penyimpanan yang di namakan dengan ruangan arsip. Karena tidak adanya ruangan arsip di Sekolah Usaha Perikanan Menengah Sorong, maka inilah salah satu yang membuat tumpukan arsip di beberapa unit ruangan belum tertatah dengan baik dan benar. Pada hal untuk instansi pemerintah menurut saya seharusnya ada yang namanya ruangan perpustakaan dan ruangan kearsipa, karena ruangan arsip itu untuk penyimpanan arsip inaktif sedangkan arsip yang aktif dalam arti kita masih sering menggunakan untuk kegiatan kantor itulah yang berada di sekitar kita atau di dekat meja kita karena masih dapat di olah lagi.

Kalau berbicara dengan arsip atau ruangan arsip pasti juga ada yang namanya alat penyimpanan arsip, alat penyimpanan arsip terdidiri dari :

- Filling Cabinet adalah tempat untuk penyimpanan arsip dinamis aktif di dalamnya ada susunan sekat dan folder secara vertikal dalam laci-lacinya, dimana penyusunannya mulai dari atas kebawah.

- Folder adalah map sebagai tempat penyimpanan arsip sehingga arsip dapat terhimpun dalam suatu wadah baik secara seri, rubrik maupun dosier, pada folder terdapat tab yang menonjol dan fungsinya untuk mencantumkan titel dan kode klasifikasi.

- Rak adalah tempat penyimpanan arsip yang terbuka, penggunaan rak lebih muda di bandingkan menggunakan filling cabinet karena tidak perlu membuka laci sebagaimana membuka filling cabinet.

- Guide atau sekat adalah alat yang digunakan sebagai batas atau petunjuk antara pokok masalah dengan rinciannya 
- Lemari adalah tempat penyimpanan yang di dalamnya menggunakan bindex-bindex agar terlihat rapi dalam penataan arsipnya

- Bindex adalah tempat untuk menaruh surat dan dokumen yang telah di bolong tepihnya untuk di simpan di lemari atau rak dll.

- Dan terutama ruangan arsip atau pusat arsip (records center)

Dalam penyimpanan arsip haru memperhatikan langkah-langkah sebagai beriku :

- Memeriksa, agar arsip atau dokumen yang selalu terkontrol keberadaannya, dan untuk mengetahui pola arsip atau dokumen.

- Mengindeks, agar menyatuhkan atau mengelompokan arsip atau dokumen dengan menggunakan kode.

- Memberi tanda atau kode, agar arsip atau dokumen untuk memudahkan penyimpanan dan mudah di temukan kembali pada saat diperluhkan.

- Menyortir, agar mengelompokan kembali arsip atau dokumen untuk di simpan atau agar di musnahkan.

- Penyimpanan, agar arsip atau dokumen dapat terjaga dan aman pada tempatnya dan tidak bertumpuk di kiri dan kanan meja kerja dll.

Penemuan kembali arsip diawali dengan adanya permintaan dari pengguna, sehingga antara peminjaman dan penemuan kembali arsip merupakan suatu hal yang berkaitan dengan ketepatan dan kecepatan dalam menemukan atau mendapatkan arsip. untuk peminjaman arsip akan sangat bergantung dari beberapa hal sebagai berikut :

- Kejelasan materi yang dimintah oleh pengguna

- Ketepatan sistem pemberkasan yang digunakan dalam pemberkasan jenis-jenis arsip

- Ketepatan dan kemantapan sistem indeks

- Ketepatan dan kemantapan sistem kode klasifikasi.

Tersediannya tenaga arsiparis yang memiliki pengetahuan dan keterampilan yang tugasnya untuk menangani kearsipan.

Untuk tenaga arsiparis pada Unit Pelaksana Teknis Sekolah Usaha Perikanan Menengah Sorong telah mempunyai 1 (satu) orang tenaga arsiparis, yang selama ini sudah menjalankan tugas sebagaimana mestinya, namun masih ada saja kendala dalam penanganan arsip pada Sekolah Usaha Perikanan Menengah Sorong, karena keterbatasan ruangan arsip dan tidak ada rak arsip, sehingga arsip yang ada belum terlaksana dengan baik dan benar, di karenakan tidak didukung dengan anggaran untuk operasional kearsipan sehingga pengelolaan arsip belum dikatakan efektif dan efisien pada Sekolah Usaha Perikanan Menengah Sorong.
Kegiatan kearsipan pada dasarnya tidak hanya saat penyimpanan saja, akan tetapi sudah di mulai sejak arsip tersebut di ciptakan, di proses, di simpan sampai akhirnya arsip tersebut di musnahkan, yang di namakan dengan pemeliharaan atau perawatan arsip, ini juga yang terdapat pada Sekolah Usaha Perikanan Menengah Sorong. Siklus hidup arsip di mulai dari kegiatan penciptaan arsip yaitu penulisan surat, memo, formulir, laporan gambar, hal ini juga di sebut sebagai korespondensi manajemen pengelolaan kearsipan.

Terkait dengan proses penciptaan arsip atau pembuatan arsip bahwa pada dasarnya arsip yang tercipta sering dengan pelaksanaan Tugas Pokok dan Fungsi masing-masing unit kerja Aparatur Sipil Negara pada Sekolah Usaha Perikanan Menengah Sorong. Arsip tercipta sebagai tindak lanjut surat masuk dan surat keluar yang diterima oleh lembaga kantor yang selanjutnya di terima oleh unit kerja terkait untuk di proses lebih lanjut. Yang dimaksud dengan unit kerja adalah bagian-bagian yang mengolah surat masuk dan surat keluar yang nanti akan menjadi arsip yang ada di Sekolah Usaha Perikanan Menengah Sorong yaitu unit kerja bagian Tata Usaha, Kepegawaian, Keuangan, Pengajaran, Kesiswaan, Hubungan Masyarakat (HUMAS) dan Sarana Prasarana Pendidikan (SARDIK), dan selanjutnya arsip dapat di kelola oleh masing-masing unit keja tersebut dalam bentuk arsip surat keluar dan arsip surat masuk, sehingga arsip disebut sebagai arsip aktif dan arsip inaktif serta arsip statis. Demikian pula langkahlangkah penataan arsip aktif surat masuk dan surat keluar, untuk arsip-arsip hasil dari unit kerja lain dikelola dengan memperhatikan prinsip asal usul arsip, arsip di kelompokan berdasarkan unit kerja pencipta, yang di kelompokan berdasarkan subjek atau kode klasifikasi, pengurutan secara numerik nomor pencatatan, dan dicatat di komputer. Arsiparsip vital dikelola dengan sistem subjek, di kelompokan berdasarkan jenis atau permasalahan arsip.

Pada dasarnya pengelolaan arsip menganut sistem disentralisasi, arsip-arsip di simpan atau dikelola masing-masing unit kerja pengola. Namun demikian ketika arsip menjadi inaktif untuk dikelola di bagian pengelola kearsipan sebagai pusat arsip di Sekolah Usaha Perikanan Menengah Sorong. hal dimaksud untuk menjaga keberadaan ruang arsip di masing-masing unit kerja juga untuk menjamin terselamatnya arsip yang kemungkinan bernilai guna sejarah, pembuktian ataupun penelitian di masa yang akan datang.

Penggunaan arsip ini dapat melalui dua cara yaitu 
dengan cara meminjam dengan cara meminta atau arsip di fotocopy. Dalam layanan peminjaman arsip, terdapat Standar Operasional Prosedur (SOP) yakni

- Pengguna formulir peminjaman arsip

- Persetujuan/disposisi kepada bagian kearsipan

- Penelusuran arsip oleh arsiparis, melalui aplikasi SIKAP dan aplikasi e-layar atau manual

- Penyerahan Arsip, bagi peminjam arsip di wajibkan mengisi formulir peminjaman terlebih dahulu

- Penyerahan fotocopy arsip

Di Bagian Tata Usaha Sekolah Usaha Perikanan Menengah Sorong mempunyai tugas pokok adalah melakukan urusan persuratan dan kearsipan, serta melakukan penyimpanan surat dan dokumendokumen di bidang ketata Usahaan, hubungan masyarakat, organiasi, perlengkapan, hukum dan keuangan. Jadi bagian tata usaha selain memiliki tugas menciptakan arsip juga mempunyai tanggung jawab menyimpan segala arsip yang berhubungan dengan lingkungan Pendidikan. Peran tanggung jawab ini tentunya sudah di bedahkan dengan unit-unit lain, seperti di keuangan, kepegawaian, pengajaran, kesiswaan, kehumasan dan sarana prasarana pendidikan, bagian tata usaha menciptakaan arsip dan penyimpanan arsip berbeda dengan yang di simpan di unit perpustakaan. Keberadaan tempat penyimpanan arsip yang ada di Unit Tata Usaha Sekolah Usaha Perikanan Menengah Sorong yang relatif sempit dan kemungkinan akan menimbulkan masalah di kemudian harinya, karena setiap hari arsip bertambah dan tentunya juga harus membutuhkan tambahan ruangan untuk penyimpanan arsip, apalagi di Sekolah Usaha Perikanan Menengah Sorong belum pernah melakukan penyusutan arsip. Pedoman umum untuk menentukan nilai guna arsip, dapat di ketahui bahwa penentuan nilai guna arsip merupakan kegiatan untuk memisahkan arsip-arsip ke dalam dua kategori yaitu arsip yang bernilai guna permanen yang terus di simpan, sedangkan arsip yang bernilai guna sementara yang dapat di musnahkan dengan segera atau di kemudian hari.

Keberhasilan dari penilaian tersebut tergantung kepada :

1. Kemantapan pengertian dan pemahaman terhadap cara dan bagaimana kegiatan instansi itu terekam dalam arsip

2. Pengertian dan kesadaran akan fungsi kegunaan arsip bagi penggunaannya serta kepentingan penyelamatan arsip sebagai bahan bukti dan bahan pertanggung jawaban.

Kegiatan tersebut penting untuk menetukan jadwal penyimpanan atau retensi arsip yang menjadi dasar pelaksanaan penyusutan arsip, sebab nilai guna arsip dapat berubah sesuai dengan kepentingan penggunaan dan fungsinya. Dalam menciptakan suatu sistem penataan arsip yang baik, hendaknya di perhatikan atau di penuhi beberapa faktor penunjang antara lain :

- Kesederhanaan adalah sistem penataan arsip yang di pilih dan di terapkan harus mudah, supaya tidak hanya di mengerti oleh satu orang, namun dapat pula di mengerti oleh orang lain

- Ketepatan penyimpanan arsip adalah berdasarkan sistem yang digunakan harus memungkinkan penemuan kembali arsip dengan cepat dan tepat - Memenuhi persyaratan ekonomis adalah untuk dapat memanfaatkan ruangan, tempat dan peralatan yang ada, serta biaya yang tersedia

- Menjamin keamanan adalah arsip harus terhindar dari kerusakan, pencurian, kemusnahan dan harus aman dari bahaya banjir, air, api dan ganguan binatang lain, sehingga penyimpanan harus di tempat yang benar-benar aman dari segalah gangguan

- Penetapan arsip hendaknya di tempatkan pada tempat yang strategis, maksudnya adalah agar tempat penyimpanan mudah di capai oleh setiap unit yang memerluhkan arsip tersebut tanpa membuang banyak waktu dan tenaga.

- Sistem yang digunakan harus fleksibel adalah harus memberikan kemungkinan adanya perubahan-perubahan dalam rangka penyempurnaan dan ketepatan kerja

- Petugas arsip adalah yang harus memahami pengetahuan di bidang kearsipan

Di dalam penyimpanan arsip harus di perhatikan masalah asas pengorganisasian arsip. arsip dinamis berupa arsip aktif dan arsip inaktif dapat di simpan dan di kelola secara sentralisasi pada suatu unit khusus di dalam organisasi yang biasa di kenal sebagai central file. Sistem penyimpanan arsip secara sentral ini makin efisien dan efektif bila di terapkan pada suatu organisasi yang relatif kecil, rentang tugasnya pendek, tidak terlalu kompleks. Beban kerja tidak terlalu besar dan tempat lokasinya tidak terpencar-pencar. Dengan menerapkan asas sentralisasi, maka sistem penyimpanan yang di gunakan akan menjadi standar pengelolaan arsip, seluruh arsip akan dapat di simpan dan di ketemukan kembali dengan aturan dan prosedur yang sama. Untuk organiasi yang relatif besar, asas penyimpanan yang tepat untuk di terapkan adalah disentralisasi. Dalam asas ini semua unit pengolah di berikan otoritas untuk menyimpan dan mengelola arsip aktifnya, masing-masing asas ini dapat diterapkan apabila organisasi mempunyai rentang tugas yang panjang, beban kerja yang besar dan lokasinya berpencar dan 
berjauhan. Disamping dua asas ini, organisasi juga dapat menerapkan asas gabungan yang merupakan kombinasi antara asas sentralisasi dan asas desentralisasi.

Prinsip asas ini adalah bahwa setiap unit pengolah di berikan otoritas untuk melakukan penyimpanan dan pengelolaan arsip dengan kontrol atau pengendalian sistem secara terpusat oleh suatu unit, khusus di dalam organisasi. Untuk melakukan penyimpanan arsip-arsip aktif ini ada beberapa yang dapat di terapkan sistem klasifikasi sebagai sistem pemberkasan, dan pemeliharaan sistem pemberkasan yang akan di gunakan sangat bergantung pada kegunaan masing-masing arsip bagi pengguna dan jenis arsip itu sendiri. Sehingga dapat terjadi beberapa arsip yang berbeda di pemberkasan dengan sistem yang berbeda pula.

Di dalam menentukan sistem pemberkasan yang akan di terapkan perlu di pertimbangkan beberapa hal di antaranya adalah bentuk arsip, sifat serta bidang-bidang kegiatan organiasi dan karakteristik organisasi yang bersangkutan. Perlu juga di perhatikan bahwa sistem pemberkasan yang akan di terapkan harus menggambarkan secara jelas bentuk berkas arsipnya, sehingga di dalam penemuan kembali dapat di lakukan secara cepat dan tepat. Suatu arsip dapat menjadi sumber informasi apabila arsip tersebut dapat di temukan kembali fisik dan isi informasinya. Hal ini sesuai dengan konsep dan pengertian yang di kemukakan bahwa unsur arsip agar dapat di katakan sebagai arsip adalah sifatnya yang dapat di ketemukan kembali, fase inilah yang namanya sistem dalam pengelolaan arsip dinamis. Penemuan kembali di lakukan apabila ada permintaan dari pengguna di sini adalah mereka yang membutuhkan informasi arsip di dalam konteks pelaksanaan kerja atau pelaksanaan fungsi-fungsi manajemen faktor-faktor yang harus di perhatikan di dalam sistem pemberkasan yang diterapkan, sarananya seperti indeks dan tunjuk silang dan juga unsur kecepatan serta ketepatan yang menjadi dasar sistem prosessnya.

Arsip inaktif dalam arti jarang di gunakan, di simpan secara terpusat pada tempat penyimpanan arsip inaktif yang sering di sebut gedung penyimpanan arsip atau pusat arsip. Di dalam pusat arsip inaktif seluruh aktifitas yang berkaitan dengan pengelolaan arsip inaktif di lakukan seperti pengolahan penyimpanan, pemeliharaan dan penyusutan serta jasa layanan untuk menjadikan gedung pusat arsip perlu di lakukan perencanaan matang dengan mempertimbangkan aspek ekonomis, efisiensi dan keamanan. Agar pusat arsip ini dapat berfungsi secara maksimal dan dapat melindungi arsip, maka dibutuhkan suatu standar gedung penyimpanan arsip. Sistem pemeliharaan arsip, upaya untuk memelihara arsip terutama di tujukan untuk melindungi, mengatasi dan mengambil tindakan-tindakan untuk menyelamatkan fisik terutama informasi arsip. di samping menjamin kelangsungan hidup arsip dari kemusnahan, Pemeliharaan arsip inaktif harus memperhatikan dua faktor pokok yang dapat menyebabkan kerusakan pada fisik arsip, sehingga perlu di lakukan tindakan untuk memelihara, menjaga dan mengamankan terhadap kerusakan kerta secara langsung. Dan faktor eksteren dari lingkungan di mana arsip tersimpan, yang dapat merusak arsip secara tidak langsung.

Bagi manajemen arsip dinamis sendiri, penggunaan komputer memberikan pengaru yang berarti terhadap proses pengolahan penyimpanan, pemeliharaan dan penyajian informasi. Pemanfaatan produk teknologi yang canggih ini menimbulkan dua hal yang sangat signifikan, pertama menimbulkan komputerisasi atau lazim disebut sebagai otomasi di bidang manajemen kearsipan. Dalam hal ini komputer banyak digunakan sebagai alat atau sarana dan prasarana teknologi untuk kebutuhan administratif, pengolahan, penyimpanan, pengaksesan dan penemuan kembali serta penyajian informsi. Komputerisasi manajemen arsip dinamis, mungkin di terapkan terhadap beberapa sub sistem di antaranya adalah :

- Manajemen formulir elektronik

- Manajemen korespondensi elektronik

- Manajemen surat elektronik

- Sistem penyimpanan arsip aktif elektronik

- Sistem penyimpanan arsip inaktif elektronik

- Sistem penemuan kembali dan penyajian informasi arsip elektronik

Arsip elektronik ini pada dasarnya juga harus di kelola di dalam suatu sistem yang berdasarkan pada prinsip-prinsip manajemen arsip dinamis. Arsip memiliki fungsi dan kegunaan yang signifikan di dalam manajemen kegiatan administrasi negara dan pelaksanaan fungsi-fungsi manajemen, karena signifikan informasinya. Maka arsip harus dikelola di dalam suatu sistem yang di sebut dengan pengelolaan manajemen arsip dinamis, yang merupakan pengelolaan terhadap keseluruhan daur hidup arsip. Dalam hal pengelolaan arsip bagi sebuah instansi pemerintah oleh Aparatur Sipil Negara sudah di tentukan dan dijelaskan pada peraturan perundangundangan yang berlaku, dan pegawai di Sekolah Usaha Perikanan Menengah Sorong sampai dengan saat ini pada khususnya telah memahami dan pada umumnya masih belum. namun pelaksanaannya terhadap kearsipan sangatlah penting bagi kehidupan negara maupun bangsa, jadi mau tidak mau harus 
mengerti tentang apa itu kearsipan, karena kita sebagai Aparatur Sipil Negara sudahlah tentu siap dengan tugas dan tanggung jawab kita sebagai abdi negara dan abdi masyarakat, dalam arti pelayanan publik. Sehingga apa yang dikatakan dengan Manajemen Kearsipan dalam Menunjang Kegiatan Administrasi Pelayanan Publik dapat berjalan secara efektif dan efisien.

\section{KESIMPULAN}

Sehubungan dengan bunyi undang-undang nomor 5 tahun 2005 tentan Aparatur Sipil Negara dan undangundang nomor 43 Tahun 2009 tentan kearsipan, maka di katakan bahwa pada Unit Pelaksana Teknis Sekolah Usaha Perikanan Menengah Sorong sebagai lembaga Pendidikan sudah seharusnya dan sepantasnya dapat mewujudkan cita-cita dan tujuan negara serta mempertahankan Negara Kesatuan Republik Indonesia, dengan mengelola dan menjaga kestabilan kearsipan sebagai aset negara atau sebagai sejarah bagi bangsa dan Negara Republik Indonesia, serta menjadi sumber informasi sarana dan prasarana bagi dunia pendidikan.

Dan kenyataannya telah terjadi sumber informasi karena didunia pendidikan banyak yang membutuhkan informasi kearsipan baik manual maupun elektronik sebagai bahan penelitian maupun pembuatan makalah, misalnya dari peserta didik maupun mahasiswa yang selalu magang atau penelitian di Sekolah Usaha Perikanan Menengah Sorong untuk mendaptkan informasi atau bukti kegiatan maupun pembelajaran yang dihasilkan dari instansi ini sebagai pedoman dan persyaratan dalam pembuatan makalah maupun studi.

Dari hal seperti itulah, maka tujuan dari terbentuknya manajemen kearsipan dalam menunjang kegiatan administrasi pelayanan publik sangatlah penting sehingga perlu di implementasikan di Sekolah Usaha Perikanan Menengah Sorong.

Keberadaan tempat penyimpanan arsip yang ada di Sekolah Usaha Perikanan Menengah Sorong relatif sempit dan kurang memadai, sehingga inaktif belum dapat di tatah dengan baik dan benar pada tempatnya. Untuk penanganan arsip yang baik dan benar juga perlu harus adanya ruangan arsip maupun yang mengelola arsip, semua ini juga harus di dukung dengan adanya Sumber Daya Manusia dan Sumber Dana bagi operasional kearsipan. Namum pada hakekatnya semua ini belum efektif di Unit Pelaksana Teknis Sekolah Usaha Perikanan Menengah Sorong. Sistem manajemen pengelolaan kearsipan pada hakekatnya berhubungan dengan organisasi yang tugasnya untuk menangani arsip, dan kelengkapan yang meliputi arsipari, peralatan arsip serta ruangan arsip.

Arsip dinamis juga terbagi atas dua yaitu arsip aktif dan arsip inakti, arsip aktif yang sewaktu-waktu dapat di perluhkan kembali apa bila di butuhkan, sedangkan arsip inaktif, arsip yang masa retensinya sudah berkurang atau jarang di perlukan dan bisa dapat di musnahkan dan apabila tidak dalam berperkara dan/atau tidak bermasalah dengan hukum. Ada juga arsip elektronik, arsip yang dapat di simpan pada kompiuter yang berupa aplikasi Sistem Informasi Kearsipan (SIKAP) dan e-layar di lingkungan Kementerian Kelautan dan Perikanan. Dan arsip yang dapat di scaner dan di simpan pada komputer. Arsip yang akan di kelola pada Sekolah Usaha Perikanan Menengah Sorong adalah arsip Dinamis yang meliputi arsip aktif dan inaktif.

Sistem manajemen pengelolaan kearsipan sangatlah penting bagi sebuah instansi pemerintah, karena pada dasarnya pekerjaan seorang administrasi adalah mengurus surat dan arsip, karena arsip berperan pesat dalam mendukung pekerjaan suatu organisasi yang dapat di katakan sebagai pedoman dalam membuat sebuah keputusan yang baik dan benar dan sebagai alat bukti yang sah bagi permasalahan hukum.

\section{SARAN}

Dari pembahasan karya ilmiah di atas dapat di pahami bahwa pada hakekatnya masih ada banyak kekurangan dalam penanganan kearsipan dan arsip, maka perlu ada yang namanya Sumber Daya Manusia dan sarana dan prasarana adalah sebagai berikut :

1. Untuk membuat suatu pekerjaan itu baik dan efektif tergantung dari pemahaman dari yang mengelola, dan ingin mendapat pengelola arsip yang handal harus di dasari dengan pelatihan atau diklat arsipari bagi pengelola arsip.

2. Kalau berbicara tentang arsip, maka harus di dukung juga dengan sarana dan prasarana seperti tempat atau ruangan arsip yang memadai

3. Berbicara tentang orang yang mengelola arsip, dan ruangan atau tempat arsip, maka perlu juga didukung dengan ekonomis atau dana operasional arsip. dan walaupun Sumber Daya Manusianya ada, namun tempatnya juga tidak ada, maka sudah tentu arsipnya tidak tertatah dengan baik dalam arti tidak sesuai dengan kriteria suatu instansi pemerintah. sehingga semua yang ada ini perlu yang namanya bantuan dana operasional arsip, agar arsip dapat di proses dengan cepat, baik, dan benar maupun efektif. Karena arsip 
adalah jatih diri suatu organisasi pemerintahan dan sebagai alat bukti yang sah, yang harus di jaga keamanan, kenyamanan dan kerahasiaannya.

\section{UCAPAN TERIMA KASIH}

Ucapan terima kasih penulis sampaikan kepada Ibu Erni Kristina Pambayuningrum, A.Pi.,M.P selaku Kepala Sekolah Usaha Perikanan Menengah Sorong, yang telah memberi izin kepada penulis dalam pembuatan karya ilmiah ini, sihingga dapat terlaksana dengan baik dan tepat waktu. Ucapan terima kasih penulis sampaikan kepada Bapak Rasman, S.Pi selaku Kepala Sub Bagian Tata Usaha SUPM Sorong, yang telah mengingatkan penulis dalam pembuatan karya ilmiah ini agar cepat selesai pada waktunya. Dan penulis juga ucapkan terima kasih kepada bapak dan ibu Aparatur Sipil Negara yang ada pada Unit Pelaksana Teknis Sekolah Usaha Perikanan Menengah Sorong tanpa terkecuali, yang telah membantu dalam membimbing, memberikan ide, masukan maupun gagasan kepada penulis, sehingga karya ilmiah ini dapat berjalan dengan sempurnah, lancar dan tepat pada waktunya, sehingga menjadi inspirasi bagi yang membutuhkan.

\section{DAFTAR PUSTAKA}

Agus Sugiarto dan Teguh Wahyono. 2005, 2013, Manajemen Kearsipan Modern. Yogyakarta: Gava Media.

Choiriyah, 2007. Manajemen Kearsipan. Sukabumi.

Dermawan, R. 2006. Pengambilan keputusaan. Bandung : Alfabeta

Fahmi, I. 2013. Manajemen pengambilan keputusan : teori dan aplikasi. Bandung : Alfabeta.
Laksmi, dkk. 2008. Manajemen Perkantoran Modern. Jakarta: Penaku

Martono, Boedi. 1994. Peanataan Berkas dalam Manajemen Kearsipan. Jakarta. Sinar Harapan

Sedarmayanti. 2003, 2008, Tata Kearsipan (Cetakan Keempat). Bandung: CV. Mandar Maju.

Suraja, Yohannes. 2006. Manajemen Kearsipan. Malang : Dioma.

Sulistyo Basuki, 2003, Manajemen Arsip Dinamis: Pengantar Memahami dan Mengelolah Informasi dan Dokumen. Jakarta : PT. Gramedia Pustaka Utama,

The Liang Gie.1996. Administrasi Perkantoran Modern (Edisi Ke Empat). Yogyakarta: LIBERTY.

Peraturan Menteri Kelautan dan Perikanan Nomor : 52/PERMEN-KP/2014 tentang Kearsipan lingkup Kementerian Kelautan dan Perikanan

Peraturan Menteri Kelautan dan Perikanan Nomor : 53/PERMEN-KP/2014 tentang Pedoman Umum Tata Naskah Dinas lingkup Kementerian Kelautan dan Perikanan

Undang-Undang Dasar Negara Republik Indonesia Tahun 1945

Undang-Undang Nomor 5 Tahun 2014 tentang Aparatur Sipil Negara (ASN)

Undang-Undang Nomor 20 Tahun 2003 tentang Sistem Pendidikan Nasional

Undang-Undang Nomor 43 Tahun 2009 tentang Kearsipan 
I. PROFIL KANTOR DAN KEADAAN PENYIMPANAN ARSIP ATAU RUANGAN ARSIP PADA SUPM SORONG
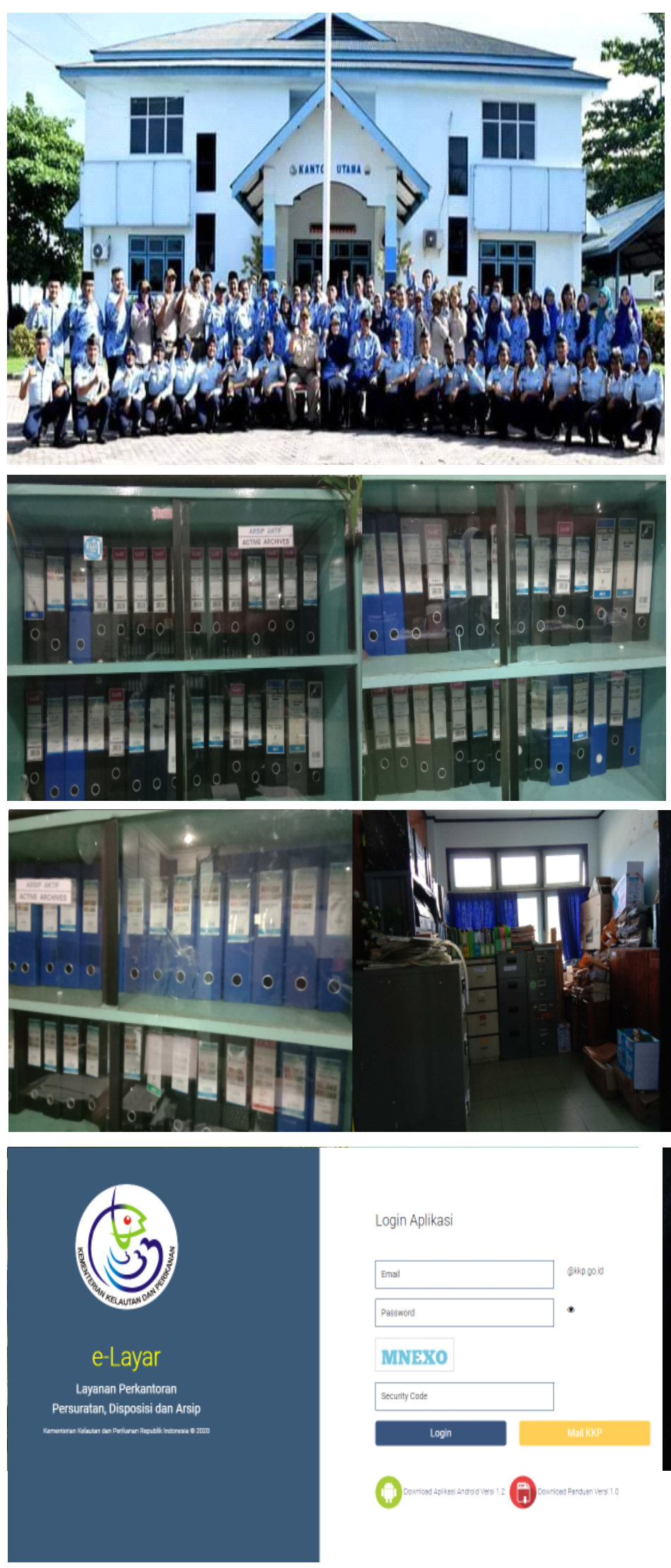

Login Aplikasi

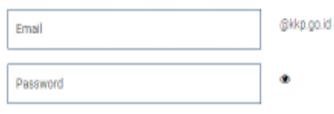

MNEXO

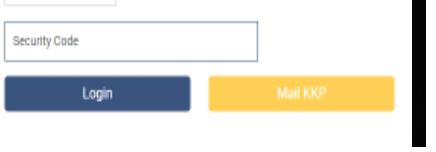

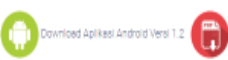

(4) 